\title{
Selection for fast growth during the larval life of Atlantic cod Gadus morhua on the Scotian Shelf*
}

\author{
Mark G. Meekan**, Louis Fortier \\ GIROQ, Département de biologie, Université Laval, Ste-Foy, Québec, Canada G1K 7P4
}

\begin{abstract}
We tested the hypothesis that fast growing Atlantic cod Gadus morhua survived better than their population of origin in the winters of 1991-1992 and 1992-1993 on the Scotian Shelf (northwest Atlantic). Survivors were defined as fish $>90 \mathrm{~d}$ of age at capture which comprised epibenthic juveniles $>20 \mathrm{~mm}$ sampled mainly near the bottom. The majority of larvae and juveniles aged $\leq 90 \mathrm{~d}$ at capture were sampled with a midwater trawl and were assumed to be representative of the pelagic population (survivors + non-survivors) from which epibenthic survivors originated. Standard length corrected for shrinkage was linearly correlated to lapillar radius $\left(r^{2}=0.97\right)$. Individual growth histories were reconstructed from the width of lapillar increments. Selection for fast growth was weak in the winter of 1991-1992 and back-calculated growth and length at age of survivors were not significantly larger than that of the population (repeated-measures MANOVA). In winter 1992-1993, a strong selection for fast growth was evident in late larvae 41 to $80 \mathrm{~d}$ old. The divergence in length at age between survivors and the population reached $4 \mathrm{~mm}$ at an age of $70 \mathrm{~d}$, corresponding to a $13 \mathrm{~d}$ reduction in the duration of the larval phase. Survivors in the winter of 1992-1993 had larger hatch marks than the population, suggesting that the potential for fast growth may be reflected in traits present at hatching. Our results support the hypothesis that fast growth increases the survivorship of Atlantic cod during larval life in the plankton and indicate that the intensity of size-selective mortality may vary considerably from year to year.
\end{abstract}

KEY WORDS: Growth selection · Fish larvae A Atlantic cod

\section{INTRODUCTION}

The eggs and larvae of marine fish experience high rates of mortality (e.g Bailey \& Houde 1989, Heath 1992, Leggett \& Deblois 1994). It is frequently argued that the extent of this mortality is dependent on growth. Larvae that grow rapidly are usually the first to achieve juvenile form and, in some species, to settle to the bottom or adopt a more epibenthic life (e.g. Chambers \& Leggett 1987, Amara \& Lagardère 1995). Thus, fast growing individuals will be exposed to planktonic predators for a shorter period of time than slower growing individuals (the match-mismatch and growth-predation hypotheses; Cushing \& Harris 1973, Anderson 1988, Cushing 1990). In addition, fast grow-

\footnotetext{
- Contribution to the research program of GIROO if irnupe interuniversitaire de recherches océanographiques du Québec)

•-E-mail:m_meekan@aims.gov.au
}

ing fish are larger and, hence, potentially less vulnerable to predators than slow growing fish of the same age (the bigger-is-better hypothesis, e.g. Miller et al. 1988, Bailey \& Houde 1989). Theoretical and simulation studies indicate that only relatively small changes in early growth rates are required to create large variations in the number of individuals surviving to recruitment (Chambers \& Leggett 1987, Houde 1987, Pepin \& Myers 1991, Cushing \& Horwood 1994). If survival is dependent on growth, the study of growth may provide a means of forecasting recruitment strength (Houde 1987).

Growth increments are deposited on a daily basis within the otoliths of many species of fish larvae and juveniles (Pannella 1971, Campana \& Neilson 1985, Stevenson \& Campana 1992). When somatic and otolith growth are linearly correlated, the width of increments may be used to back-calculate the growth histories of individual fish (Campana 1990, Campana \& Jones 1992). The intensity and ontogenetic timing of selection 
for fast growth and large size can be investigated by comparing the growth records of surviving individuals with those of the population at earlier times (Rosenberg \& Haugen 1982, Post \& Prankevicius 1987, Tsukamoto et al, 1989, Hovenkamp 1992). An important assumption of this approach is that the same cohort or population of young fish is repeatedly sampled through time. The eggs and larvae of Atlantic cod Gadus morhua are retained throughout larval development on the banks off the eastern coast of Canada and the United States (e.g. Gagné \& O'Boyle 1984, O’Boyle et al. 1984, Sherman et al. 1984, Smith \& Morse 1985). By sampling in the region of banks with a variety of gear types, populations of young cod can be followed from hatching until individuals become epibenthic at the end of pelagic life (Suthers \& Frank 1989).

In this study, individual growth histories back-calculated from lapillar increment width were used to test the hypothesis illấ fást growing Atlantic cod larvae survived better than the population from which they originated in the winters of 1991-1992 and 1992-1993 on the Scotian Shelf. Survivors were defined as fish $>90 \mathrm{~d}$ of age at capture, most of which had adopted an epibenthic distribution. The back-calculated growth and length at age of survivors during larval life were compared to that of fish $\leq 90 \mathrm{~d}$ at capture which were assumed to be representative of the pelagic population (survivors + non-survivors) from which epibenthic survivors originated. In particular, we compared the intensity and ontogenetic timing of selection for fast growth between the 2 winters and looked for evidence that any potential for fast growth selected during early life in the plankton is reflected in the hatch mark diameter of survivors.

\section{MATERIALS AND METHODS}

Sampling. Ichthyoplankton surveys were conducted at monthly intervals from March 1991 to May 1993 on a grid of 45 sampling stations west of Sable Island (Scotian Shelf, northwest Atlantic) (Fig. 1). The grid encompassed Sable Island Bank, Western Bank and Emerald Bank. Based on the abundance of eggs and yolk-sac larvae during the monthly surveys, the most significant spawning activity of Atlantic cod occurred in late autumn and early winter in 1991-1992 and 1992-1993 (Fortier \& Meekan unpubl. data) Larvae and pelagic juveniles spawned at this time were repeatedly sampled over the station grid until the transition to epibenthic life in the spring. Epibenthic juveniles were captured over the shallowest part of Sable Island Bank in the grid area.

Weather permitting, a rectangular midwater trawl (RMT) was deployed at each station of the grid on each.

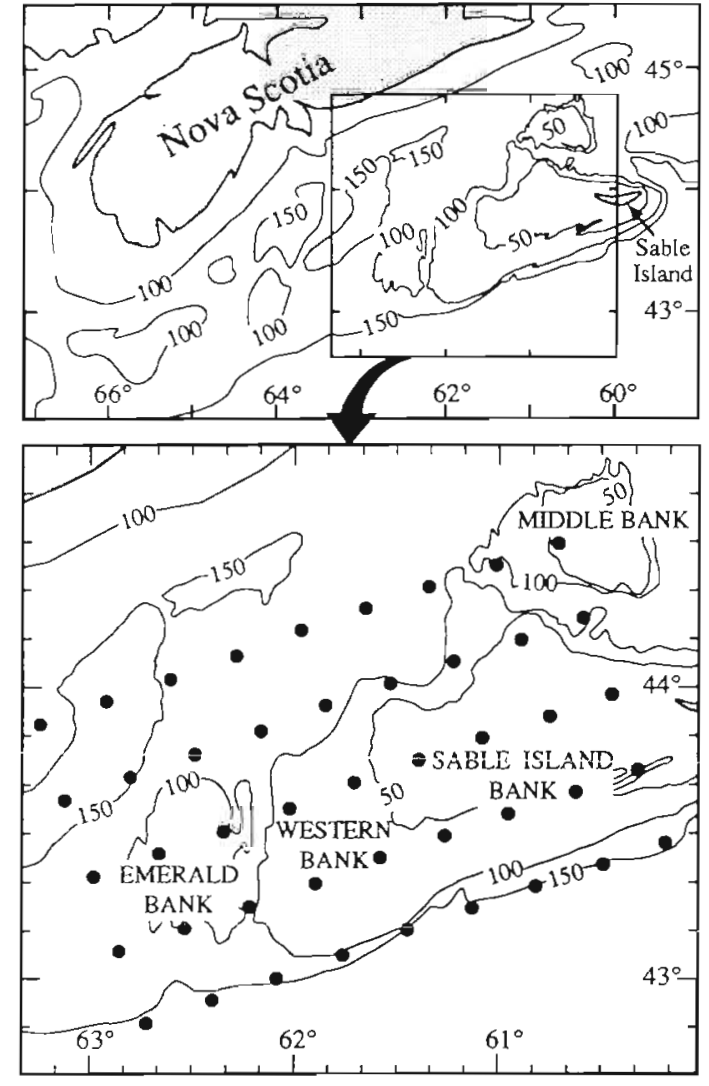

Fig. 1 Location of the grid of 45 sampling stations west of Sable Island on the Scotian Shelf. Isobaths are in metres

of the monthly surveys. Yolk-sac and early post yolksac larvae of Atlantic cod were sampled by the small, upper net of the RMT $\left(2 \mathrm{~m}^{2}\right.$ effective aperture, $333 \mu \mathrm{m}$ mesh). The large lower net $\left(8 \mathrm{~m}^{2}\right.$ effective aperture, $1600 \mu \mathrm{m}$ mesh) targeted larger larvae and pelagic juveniles. The RMT was deployed in a multiple oblique haul from the surface to $75 \mathrm{~m}$ or to within $5 \mathrm{~m}$ of the bottom at stations shallower than $75 \mathrm{~m}$. The sampler was towed for $17 \pm 5$ min (mean \pm SD) at a speed of approximately 2 knots $\left(1 \mathrm{~m} \mathrm{~s}^{-1}\right)$. A CTD and flowmeters linked to a computer onboard allowed for the constant monitoring of sampler depth, water temperature, salinity and volume filtered by each net.

To capture epibenthic juveniles, 2 nets $\left(1 \mathrm{~m}^{2}\right.$ aperture each, $1 \mathrm{~cm}$ mesh, $250 \mu \mathrm{m}$ mesh in the cod end region) mounted adjacent on a metal frame were towed just above the bottom for $22 \pm 4 \mathrm{~min}$ at a speed of 2 knots The tow line with depressor was attached to the centre of the metal frame to avoid affecting the path sampled by the nets. This epibenthic sampler was deployed on $12 \pm 6$ occasions on average on each of the surveys.

The majority of fish larvae and all juveniles were immediately sorted from the samples at sea and preserved in $95 \%$ ethanol. A subset of Atlantic cod larvae 
and juveniles were videotaped before preservation in ethanol. The linear regression of fresh standard length (SL, obtained from the videotape) on standard length after preservation in ethanol (PSL) was $\log \mathrm{SL}=0.056$ $+0.978 \log$ PSL, $n=337, \mathrm{r}^{2}=0.98$ ( T J. Miller, T Herra \& W C. Leggett unpubl data). The PSL of all fish was measured and the above equation was used to calculate SL

Otolith analysis. For each survey, catches of Atlantic cod were summed into $5 \mathrm{~mm}$ standard length classes (after correction for shrinkage in ethanol). A subsample of up to 80 larvae and juveniles from each size class was then retained for otolith analysis. For a given size class, fish were selected from a survey in proportion to the contribution of that survey to the overall abundance of the size class summed over all surveys. This stratified subsampling yielded a total of 522 and 424 cod from the first $(1991-1992)$ and second $(1992-1993)$ winters respectively. The sagittae and lapillae of each of these larvae were removed under a dissecting microscope with a polarized light source. Otoliths were mounted on glass slides with cyanoacrylate glue (Campana \& Hurley 1989). Both lapillae were ground on lapping film to the plane of the core and the number of daily increments counted at $1250 \times$ magnification. When a consistent and comparable age (within $15 \%$ ) could not be obtained for both lapillae of a pair, the data was discarded (ca $8 \%$ of cases). One of the 2 lapillae was chosen at random and increments widths were measured by projecting the microscope image (at $1250 \times$ magnification) onto a video screen using a video camera. The screen was linked to a computer and the measurements made using an image analysis system (OPTIMAS). Increments were always analyzed along a transect from the core to the edge in the same region of the lapillus (see Fig. 2 in Suthers et al. 1989 for transect location).

Lapillae were selected for analysis for a number of reasons. Many studies have demonstrated that increments are laid down at daily intervals within lapillae of larval cod (Bergstad 1984, Dale 1984, Campana \& Hurley 1989, Geffen 1995), until at least 2 mo after hatching (Suthers \& Sundby 1993). The lapillae also grow faster than the sagittae during the first $25 \mathrm{~d}$ after hatching (Bergstad 1984), facilitating the resolution of fine increments close to the hatch mark. Lapillae are thinner than sagittae at most ages, reducing the amount of grinding required to reveal the plane of the core. Additionally, accessory primordiae are often formed in the sagittae at ages of approximately 80 to $100 \mathrm{~d}$, complicating the interpretation of increment measurements.

The assumption of proportionality between otolith givovitı airc sulldiic growth was ventued by the strong straight-linear relationship between lapillar radius and standard length of larvae corrected for shrinkage

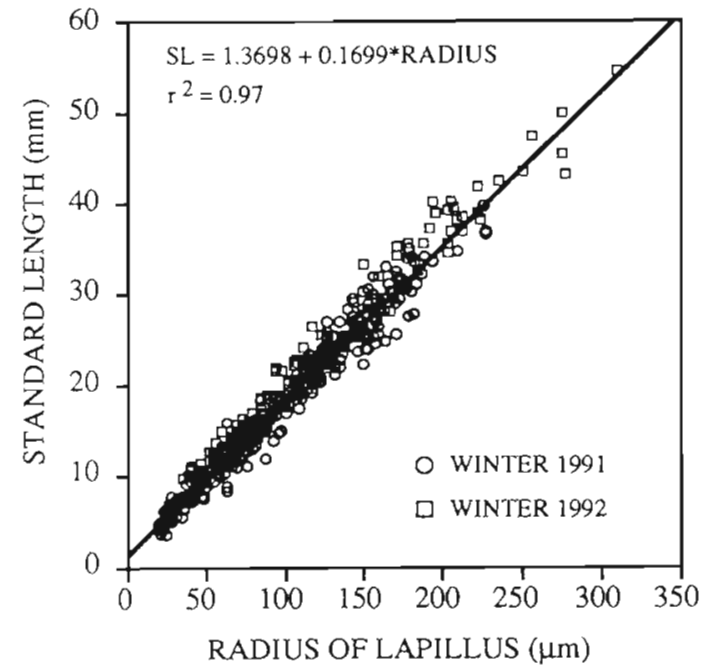

Fig. 2. Gadus morhua. Relationship between radius of lapillus and standard length of Atlantic cod larvae sampled on the Scotian Shelf in winters 1991-1992 and 1992-1993. Data were pooled over the 2 winters for the regression. Standard length was corrected for shrinkage (see 'Materials and methods')

(Fig. 2). The slope and intercept of the regression line did not differ significantly between the 2 winters (ANCOVA, $p=0.91$ ). The standard length at age of individual larvae was back-calculated from lapillar increment widths, using the biological intercept method (Campana 1990, Campana \& Jones 1992). A hatching length of $3.5 \mathrm{~mm}$ (Fahay 1983) and a lapillus diameter of $28 \mu \mathrm{m}$ (modal value of the normally distributed hatch mark diameter of the larvae used in the present analysis) were used as biological intercepts.

Data analysis. We defined survivors as Atlantic cod aged $>90 \mathrm{~d}$ at capture. This $90 \mathrm{~d}$ age boundary between population and survivors corresponded broadly to the higher part of the range of ages of juvenile Atlantic cod at the transition from a pelagic to a more epibenthic life (50 to $100 \mathrm{~d}$; Bolz \& Lough 1988) which occurs between 25 and $50 \mathrm{~mm}$ in length (Fahay 1983, Perry \& Neilson 1988). Thus, survivors as defined here consisted of juvenile fish $>25 \mathrm{~mm}$ long that were expected to be primarily epibenthic. Population fish consisted of larvae and newly metamorphosed pelagic juveniles $<25 \mathrm{~mm}$. Average growth rate $\left(\mathrm{mm} \mathrm{d}^{-1}\right)$ and specific growth rate $\left(\% \mathrm{~d}^{-1}\right)$ over $10 \mathrm{~d}$ intervals from hatching up to $80 \mathrm{~d}$ of age, and length at the end of each 10 d interval, were back-calculated for each fish $10 \mathrm{~d}$ and older.

Ideally, the back-calculated growth of survivors over a given growth interval should be compared with that of (population) fish captured immediately at the end of this growth interval. For example, the back-calculated growth of survivors over the growth interval 1 to $10 \mathrm{~d}$ should preferentially be compared with that of fish $11 \mathrm{~d}$ old at capture, which have not been subjected to 
Table 1. Gadus morhua. Number (N) and range of age at capture of fish used to represent the population in the comparison (repeated-measures MANOVA) of back-calculated growth rates and length at age among groups of Atlantic cod sampled in the winters of 1991-1992 and 1992-1993 on the Scotian Shelf. The 4 groups of fish in the MANOVA were survivors (fish >90 d at capture) in the first winter, survivors in the second winter, population (fish $\leq 90 \mathrm{~d}$ at capture) in the first winter and population in the second winter. Thus, the 62 fish used in the calculation of the average population growth rate over the 1 to $10 \mathrm{~d}$ growth interval in the first winter ranged from 11 to $30 \mathrm{~d}$ of age at capture (see text). The age at capture of survivors ranged from 91 to $186 \mathrm{~d}$ in the first winter $(\mathrm{N}=100)$ and from 91 to $154 \mathrm{~d}$ in the second winter $(N=54)$

\begin{tabular}{|lcccc|}
\hline $\begin{array}{l}\text { Growth } \\
\text { interval } \\
\text { (d post hatch) }\end{array}$ & $\begin{array}{c}\text { Winter 1991-1992 } \\
\text { Range of age } \\
\text { at capture (d) }\end{array}$ & $\begin{array}{l}\text { Winter 1992-1993 } \\
\text { N }\end{array}$ & $\begin{array}{c}\text { Range of age } \\
\text { at capture (d) }\end{array}$ \\
\hline $1-10$ & 62 & $11-30$ & 52 & $11-60$ \\
$11-20$ & 63 & $21-45$ & 54 & $21-60$ \\
$21-30$ & 66 & $31-50$ & 62 & $31-70$ \\
$31-40$ & 67 & $41-60$ & 46 & $41-70$ \\
$41-50$ & 41 & $51-75$ & 42 & $51-80$ \\
$51-60$ & 46 & $61-85$ & 40 & $61-85$ \\
$61-70$ & 59 & $71-90$ & 46 & $71-90$ \\
$71-80$ & 42 & $81-90$ & 30 & $81-90$ \\
\hline
\end{tabular}

additional growth- or size-dependent selection after the 1 to $10 \mathrm{~d}$ growth interval. Unfortunately, contrary to controlled experiments in which hatching is often synchronous, field collections will seldom yield a sufficient number of fish of precisely the right age at capture for statistical comparisons. To obtain adequate sample sizes for the population, we used the back-calculated growth of fish older at capture than the upper limit of the growth interval considered. For example, in the first winter, the age at capture of the 62 fish used in the calculation of the average growth rate of the population over the 1 to $10 \mathrm{~d}$ growth interval ranged from 10 to $30 \mathrm{~d}$ (Table 1). In the first winter, fish up to $25 \mathrm{~d}$ older than the upper limit of the interval were abundant enough to obtain adequate sample sizes. Fewer Atlantic cod larvae were captured in the second winter and fish up to $50 \mathrm{~d}$ older than the upper limit of the growth interval had to be included in the reference population for the earliest growth intervals (Table 1). A consequence of this procedure is that our estimate of the magnitude of any selection for fast growth will be conservative, especially in the second winter, since fast growing fish already selected by growth- or sizedependent survival may be included in the reference population against which survivors are compared.

The growth of fish is autocorrelated among growth intervals, i.e. fastest growing fish in a growth interval tend to be the fastest growing fish in the next growth interval (e.g. Rosenberg \& Haugen 1982). In addition, in the present analysis, the same fish are used in the back-calculation of growth and length over different growth intervals during the ontogeny. Accordingly, among group differences in average growth rate, average specific growth rate and average length at age were analyzed by repeated-measures MANOVA (Girden 1992, Chambers \& Miller 1995). The 4 groups of fish compared were the population in the first winter $\left(P_{1}\right)$, survivors in the first winter $\left(S_{1}\right)$, the population in the second winter $\left(\mathrm{P}_{2}\right)$ and survivors in the second winter $\left(\mathrm{S}_{2}\right)$. The response variable (growth interval) had 8 levels corresponding to $10 \mathrm{~d}$ intervals in the age span 1 to $80 \mathrm{~d}$. The Box-Cox-Bartlett iterative procedure (Sokal \& Rohlt 1981, p. 425) was used to determine the optimal power transformation to improve normality and homogeneity of variance of the growth rates and length at age data. Transformed growth rates and lengths at age for the 1 to $10 \mathrm{~d}$ interval and lengths at age for the 71 to $80 \mathrm{~d}$ interval still violated assumptions of homogeneity of variances and were excluded from the MANOVA. Wilk's $\Lambda$ was used as the test statistic. As sample size varied among growth intervals and groups of larvae (Table 1), least square means were used to compare groups. The significance level for these post hoc tests was set at $\alpha=0.05 / 6$, where the denominator is the number of comparisons among groups per growth interval

Following Healey (1982) and Hovenkamp (1992), the intensity of selection for fast growth was quantified by comparing the frequency distributions of growth rates between survivors and the population. For a given $10 \mathrm{~d}$ growth interval, a survival ratio $S R$ was calculated for each of 13 classes in the frequency distributions of growth rates: $S R=F_{\mathrm{s}} / F_{\mathrm{p}}$, where $F_{\mathrm{s}}$ and $F_{\mathrm{p}}$ are the frequencies of the class in the frequency distribution for survivors and the population respectively. $S R$ is a rough estimate of the survivorship of fast growing fish relative to slow growing fish (Hovenkamp 1992).

\section{RESULTS}

\section{Hatch date distribution of Atlantic cod selected for growth analysis}

The back-calculation of hatch dates indicated that Atlantic cod larvae and juveniles in the subset of fish retained for growth analysis were hatched from early November to early February in 1991-1992 (481. fish) and from mid October to late February in 1992-1993 (388 fish). However, in both winters, survivors (i.e. fish $>90 \mathrm{~d}$ of age at capture) were hatched primarily from early November to early January, with a large peak in hatch dates occurring in late November (Meekan \& Fortier unpubl. data). To ensure that within-season comparisons of growth and length at age were made 
on fish issued from the same cohort and that interannual comparisons were made on fish sampled in the same season of the 2 years, only fish hatched from 14 November to 4 January in 1991-1992 (313 fish) and from 12 November to 3 January in 1992-1993 (161 fish) were used in the analysis. In 1991-1992, the population comprised 213 fish ranging from 10 to $90 \mathrm{~d}$ of age at capture, while survivors included 100 fish from 91 to $186 \mathrm{~d}$ old at capture. In 1992-1993, the population was represented by 107 fish ranging from 31 to $90 \mathrm{~d}$ of age at capture and survivors included 54 individuals aged from 91 to $154 \mathrm{~d}$.

\section{Length frequency distribution of Atlantic cod in the two sampling gears}

In winter 1991-1992, the standard length at capture of fish selected from the RMT collections (333 and $1600 \mu \mathrm{m}$ mesh nets) for growth analysis ranged from $3 \mathrm{~mm}$ (i.e. approximate length at hatching) to $37 \mathrm{~mm}$ (Fig. 3a). Fish selected from the epibenthic sampler ranged from 6 to $40 \mathrm{~mm}$ in length (Fig. 3b). Some survivors were found in the RMT collections, but most $(65 \%)$ came from the epibenthic sampler. Differences between the RMT and the epibenthic sampler in the length frequency distribution (Kolmogorov-Smirnov 2-sample test, $p=0.625$ ) and the average length of

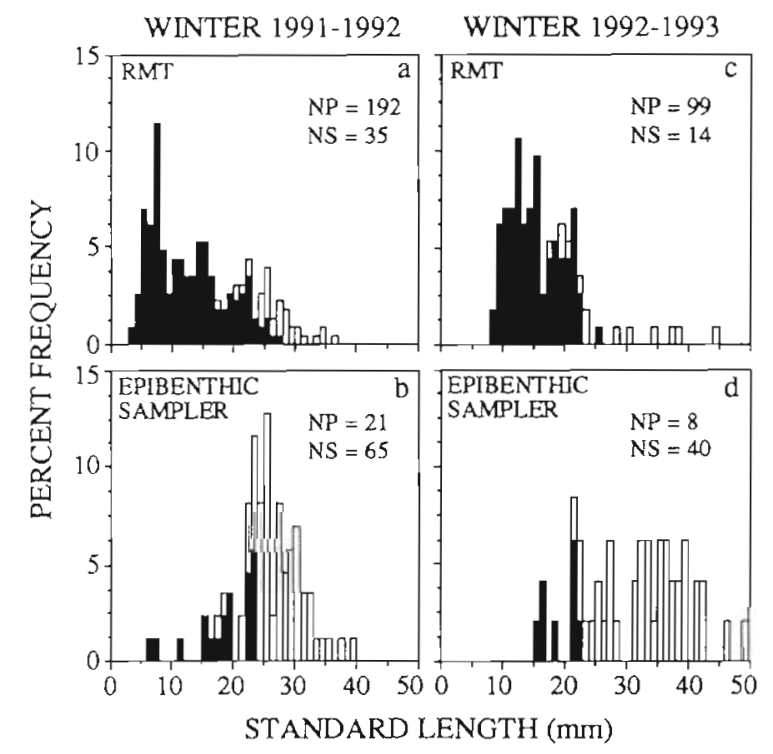

Fig. 3. Gadus morhua. Percent length frequency distribution of Atlantic cod population (full bars, fish $\leq 90 \mathrm{~d}$ of age at capture) and survivors (open bars, fish $>90 \mathrm{~d}$ of age at capture) in the rectangular midwater trawl (RMT, 333 and $1600 \mu \mathrm{m}$ mesh nets combined) and the epibenthic sampler in the winters of 1991-1992 and 1992-1993 on the Scotian Shelf NP and NS are the number of fish for the population and survivors respectively survivors ( $t$-test, $\mathrm{p}=0.768$ ) were not statistically significant.

In winter 1992-1993, the length of Atlantic cod selected for growth analysis ranged from 8 to $45 \mathrm{~mm}$ in the RMT collections and from 15 to $50 \mathrm{~mm}$ in the epibenthic sampler (Fig. 3c, d). Again, a majority of the survivors $(74 \%)$ were found in the epibenthic sampler (Fig. 3). Differences between the RMT and the epibenthic sampler in the length frequency distribution of survivors were marginally significant (KolmogorovSmirnov 2-sample test, $p=0.047$ ) whereas the average length did not differ significantly ( $t$-test, $p=0.104$ ).

Survivors were significantly older $(118$ vs $110 \mathrm{~d}, t$ test, $\mathrm{p}=0.014$ ) and larger (32.7 vs $27.3 \mathrm{~mm}$, $t$-test, $\mathrm{p}<$ 0.001 ) in the second winter than in the first winter (pooled data from the 2 sampling gears). The age frequency distribution and the size frequency distribution of survivors were significantly shifted towards larger values in the second winter (Kolmogorov-Smirnov 2 -sample test, $p<0.001$ ).

\section{Average back-calculated growth rates and length at age of survivors and populations}

The age by group interaction was highly significant for all 3 growth variables (repeated-measures MANOVA, growth: $F=2.7, \mathrm{p}=0.0002$; specific growth: $F=3.1, \mathrm{p}=0.0001$; length at age: $F=3.6, \mathrm{p}=0.0001$ ), indicating significant differences among the growth trajectories of the 4 groups of fish $\left(P_{1}, S_{1}, P_{2}, S_{2}\right)$.

In both years, the average growth rate $\left(\mathrm{mm} \mathrm{d}^{-1}\right)$ of survivors and populations increased rapidly initially, reached a maximum between 41 and $60 \mathrm{~d}$ and then declined (Fig. 4a). In the first winter, the growth trajectories of the survivors and the population were essentially parallel (Fig. 4a). The relatively small divergence between the 2 curves was not significant (repeatedmeasures MANOVA, Table 2). In the second winter, the average growth rate of the survivors was significantly higher than that of the population during the last 4 growth intervals (Fig. $4 \mathrm{a}$, Table 2). The average growth rate of the populations also differed between winters: the population in the first winter grew significantly slower than the population in the second winter during the 11 to 20 and 21 to $30 \mathrm{~d}$ growth intervals (Table 2), with this trend reversing in the following growth intervals (Fig. 4a).

Specific growth generally declined throughout the first 80 d of life (Fig. 4 b). Within a given year, the specific growth rate of survivors seldom differed from that of the population: significant differences were found only at 61 to $70 \mathrm{~d}$ after hatching in the first winter and at 51 to $60 \mathrm{~d}$ after hatching in the second winter (Table 2). Interannually, the specific growth rate of 

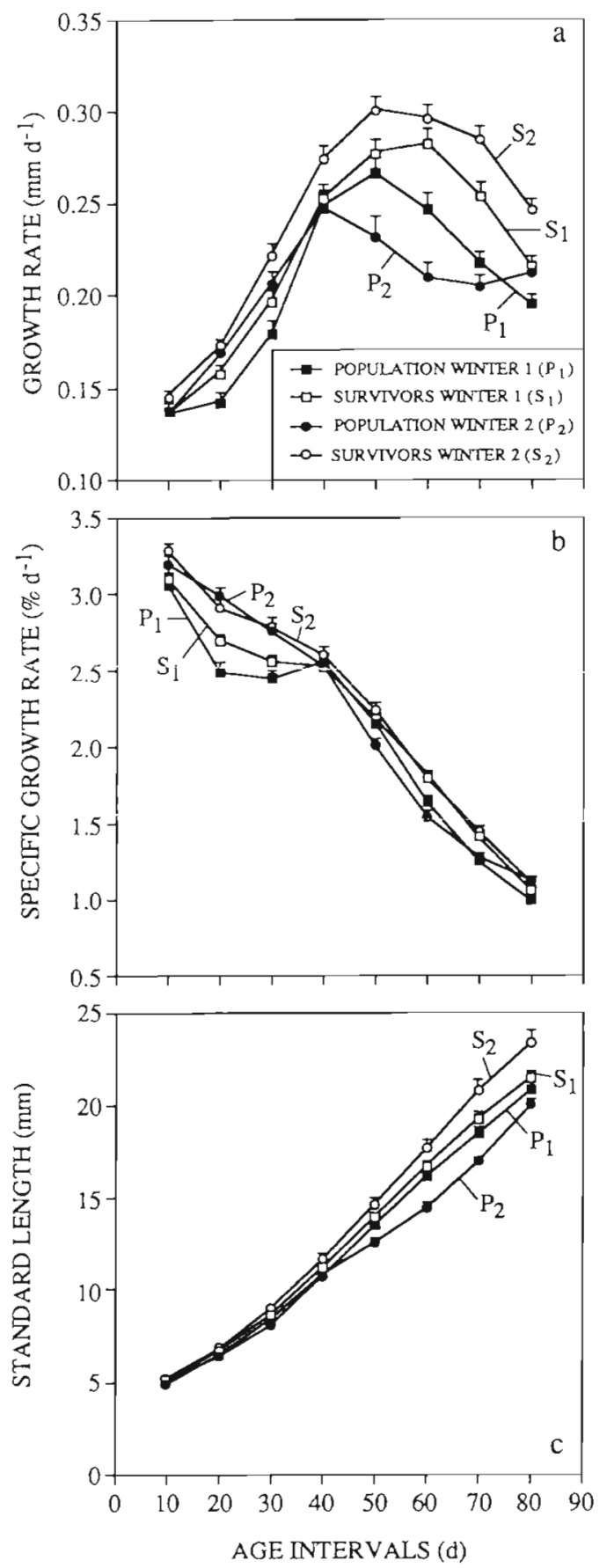

Fig. 4. Gadus morhua. Average (+1 SD) (a) back-calculated growth rate, (b) specific growth rate and (c) standard length at end of growth interval, over $10 \mathrm{~d}$ growth intervals from 0 to $80 \mathrm{~d}$ of age, for survivors and the population of Atlantic cod sampled in the winters of 1991-1992 and 1992-1993 on the Scotian Shelf. Sample sizes for each growth interval are given in Table 1

both survivors and population over the growth interval 11 to $30 \mathrm{~d}$ post hatch was significantly lower in 1991-1992 than in 1992-1993 (Fig. 4b, Table 2). In the first winter, specific growth rate of both survivors and population declined sharply over the 11 to $20 \mathrm{~d}$ growth interval, then stabilized over the 21 to $40 \mathrm{~d}$ growth interval, to finally catch up at $40 \mathrm{~d}$ with the specific growth rate of survivors and population in the second winter (Fig. 4b).

Differences in length at age among groups of fish generally reflected the observed differences in growth rates. In the first winter, survivors were on average $<1 \mathrm{~mm}$ longer at age than the population (Fig. 4c) and differences between the 2 groups in average back-calculated length at age were not significant (Table 2). In the second winter, the average survivor was significantly larger than the population for ages $>41 \mathrm{~d}$ after hatching (Table 2). The average length advantage of survivors over the 41 to $80 \mathrm{~d}$ age interval was approximately $2.8 \mathrm{~mm}$ and reached $4 \mathrm{~mm}$ at $70 \mathrm{~d}$ of age (Fig. 4c). Interannually, length at age of the population differed between winters, with the population in the first year attaining significantly larger sizes at 60 and $70 \mathrm{~d}$ after hatching than the population in the second year.

At the individual level, the increasing divergence in the second winter between the survivors and the population can be illustrated by comparing the frequency distributions of growth and length at age for selected growth intervals (Fig. 5). For the 1 to $10 \mathrm{~d}$ growth interval, the frequency distributions of growth rate and length at age were similar for the survivors and the population. For the 21 to $30 \mathrm{~d}$ interval, the distribution of growth rate of survivors was slightly shifted towards higher values relative to the population, and survivors larger than the population appeared in the frequency distribution of length at age. For the 50 to 60 d interval, the distribution of growth rates and lengths at age of survivors extended to higher values when compared to those of the population. While the frequency distribution for survivors became progressively enriched with fast growth rates and long lengths at age, some survivors still presented growth rates and length at age that were within the range of values of the population, even late in larval life (e.g. 51 to $60 \mathrm{~d}$ growth interval) (Fig. 5).

In the winter 1991-1992, fish growing at rates $\leq 0.12 \mathrm{~mm} \mathrm{~d}^{-1}$ in the interval 1 to $40 \mathrm{~d}$ post hatch and $\leq 0.16 \mathrm{~mm} \mathrm{~d}^{-1}$ in the interval 21 to $50 \mathrm{~d}$ presented survival ratios lower (0 to 0.45 ) than the value of 1 expected in the case of no selection for fast growth (Table 3). Fish growing at rates $>0.32 \mathrm{~mm} \mathrm{~d}^{-1}$ in the interval 21 to $80 \mathrm{~d}$ post hatch often showed survival ratios $>2$. In winter $1992-1993$, fish growing $\leq 0.24 \mathrm{~mm}$ $\mathrm{d}^{-1}$ during the 31 to $80 \mathrm{~d}$ growth interval survived poorly $(S R=0$ to 0.78$)$, whereas fish growing at rates $>$ $0.32 \mathrm{~mm} \mathrm{~d}^{-1}$ in the interval 21 to $80 \mathrm{~d}$ post hatch generally presented a high survivorship (SR $>3$, Table 3 ). 


\section{Hatch mark diameter of survivors and population}

In Atlantic cod otoliths, a broad mark is laid down adjacent to the core at the time of hatching (Bergstad 1984, Dale 1984). We compared the frequency distribution of hatch mark diameters between survivors and the population for each winter. Survivors were again defined as fish $>90 \mathrm{~d}$ of age at capture. In order to opti. mize sample sizes, groups of fish aged 1 to 40,41 to 60 and 61 to $90 \mathrm{~d}$ at capture were used to represent the population at different ages. There was no significant difference in the distribution of hatch mark diameters

Table 2. Gadus morhua. Within-winter (survivors vs population) and interannual (population vs population and survivors vs survivors) comparisons (repeated-measures MANOVA) of growth $\left(\mathrm{G}, \mathrm{mm} \mathrm{d}^{-1}\right)$, specific growth (S $\left(i, \% \mathrm{~d}^{-1}\right)$ and standard length at age $(\mathrm{SL}, \mathrm{mm})$ back-calculated over $10 \mathrm{~d}$ growth intervals during the pelagic life of Atlantic cod on the Scotian Shelf in the whters of 1991-1992 and 1992-1993. The 4 groups in the 1-factor MANOVh were population in first winter $\left(\mathrm{P}_{1}\right)$, survivors in first winter $\left(S_{1}\right)$, population in second winter $\left(\mathrm{P}_{2}\right)$, and survivors in second winter $\left(\mathrm{S}_{2}\right)$. Interannual comparisons between survivors and population are not presented. Signifjcance levels were adjusted for the number of comparisons (6) in each growth interval: $\alpha=0.05 / 6$. - non-significant; nt: no test

\begin{tabular}{|c|c|c|c|c|c|c|c|c|c|c|c|c|}
\hline \multirow{2}{*}{$\begin{array}{l}\text { Growth } \\
\text { interval (d) }\end{array}$} & \multicolumn{3}{|c|}{ Winter 1991-1992 } & \multicolumn{3}{|c|}{ Winter 1992-1993 } & \multicolumn{3}{|c|}{ Interannual $\mathrm{P}_{1}$ vs $\mathrm{P}_{2}$} & \multicolumn{3}{|c|}{ Interannual $\mathrm{S}_{1}$ vs $\mathrm{S}_{2}$} \\
\hline & $G$ & SG & SL & $G$ & SG & SL & $G$ & SG & $\mathrm{SI}$ & G & $\mathrm{SG}$ & SL \\
\hline $11-20$ & - & - & - & - & - & $\mathrm{S}_{2}>\mathrm{P}_{2}$ & $\mathrm{P}_{2}>\mathrm{P}_{1}$ & $\mathrm{P}_{2}>\mathrm{P}_{1}$ & - & - & $S_{2}>S_{1}$ & - \\
\hline $21-30$ & - & - & - & - & - & - & $\mathrm{P}_{2}>\mathrm{P}_{1}$ & $P_{2}>P_{1}$ & - & $\mathrm{S}_{2}>\mathrm{S}_{1}$ & $\mathrm{~S}_{y}>\mathrm{S}_{1}$ & - \\
\hline $31-40$ & - & - & - & - & - & - & - & - & - & $\mathrm{S}_{2}>\mathrm{S}_{2}$ & - & - \\
\hline $41-50$ & - & - & - & $\mathrm{S}_{2}>\mathrm{P}_{2}$ & - & $\mathrm{S}_{2}>\mathrm{P}_{2}$ & - & - & - & $S_{2}>S_{1}$ & - & - \\
\hline $51-60$ & - & - & - & $\mathrm{S}_{2}>\mathrm{P}_{2}$ & $\mathrm{~S}_{2}>\mathrm{P}_{2}$ & $\mathrm{~S}_{2}>\mathrm{P}_{2}$ & - & - & $\mathrm{P}_{2}<\mathrm{P}_{1}$ & - & - & $S_{2}>S_{1}$ \\
\hline $61-70$ & - & $S_{1}>P_{1}$ & - & $\mathrm{S}_{2}>\mathrm{P}_{2}$ & - & $\mathrm{S}_{2}>\mathrm{P}_{2}$ & - & - & $\mathrm{P}_{2}<\mathrm{P}_{1}$ & - & - & - \\
\hline $71-80$ & - & - & $\mathrm{nt}$ & $\mathrm{S}_{2}>\mathrm{P}_{2}$ & - & nt & - & $P_{2}>P_{1}$ & nit & $S_{2}>S_{1}$ & - & $n t$ \\
\hline
\end{tabular}
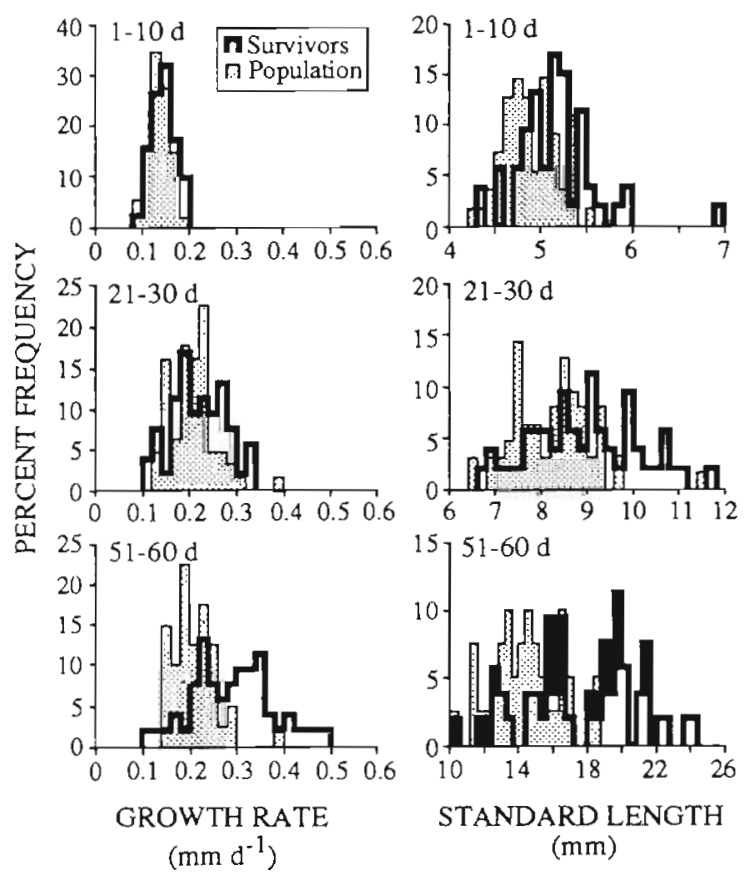

STANDARD LENGTH

(mm)

Fig. 5. Gadus morhua. Frequency distribution of back-calculated growth rate and standard length at the end of the growth interval for Atlantic cod survivors and the nnpulation over 3 growth intervals during pelagic life in the second winter of sampling (1992-1993). Sample sizes for each distribution are given in Table 1
WINTER 1991-1992 WINTER 1992-1993

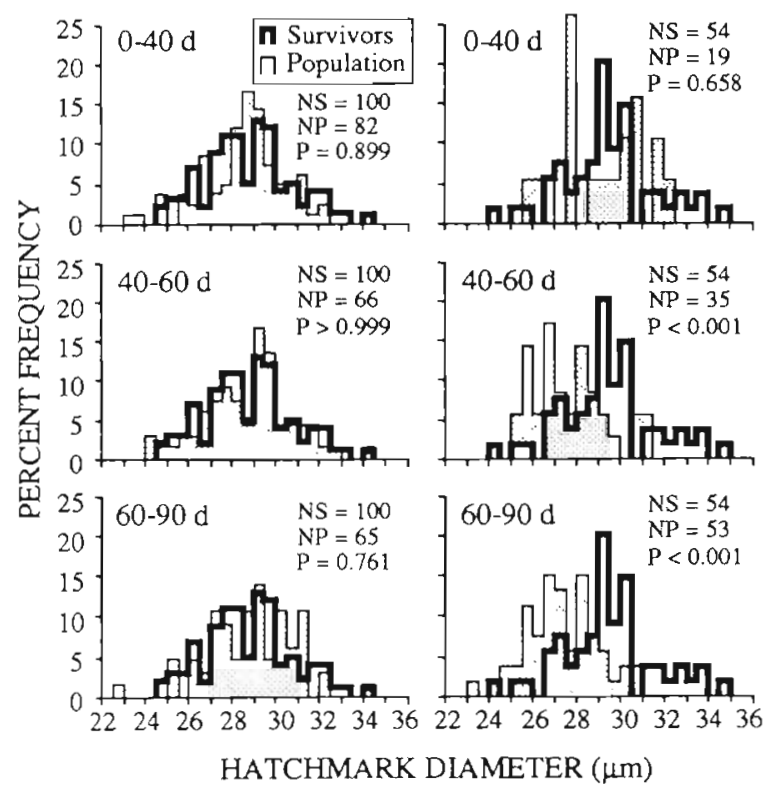

Fig. 6 Gadus morhua. Superimposed frequency distributions of hatch mark diameter of survivors (fish aged $>90 \mathrm{~d}$ at capture) and the population at different age (fish 0 to 40,41 to 60 and 61 to go d at capture) in the first $\{1991-1992\}$ andu secullu willters (1992-1993) of sampling on the Scotian Shelf. The probability (p) of observing by chance an equal or larger difference between the 2 distributions is given (Kolmogorov-Smirnov 2-sample test) 
Table 3. Gadus morhua. Survival ratıo $(S R)$ of Atlantıc cod in relation to back-calculated growth during the larval and pelagic juvenile stages in the winters $1991-1992$ and 1992-1993 on the Scotian Shelf. For a given growth interval, $S R=F_{s} / F_{\mathrm{p}}$, where $F_{s}$ and $F_{p}$ are the relative frequencies of the growth rate class in the frequency distribution of growth rates of survivors and population respectively (see 'Materials and Methods'). $S R$ is null when the class of growth rate is not represented in the survivors; infinite $(\infty)$ when the class is not represented in the population; and indeterminate $(-i)$ when the class is represented in neither the population nor the survivors. Sample sizes for each growth interval (number of fish in the frequency distribution of population and survivors) are given in Table 1

\begin{tabular}{|c|c|c|c|c|c|c|c|c|}
\hline \multirow{2}{*}{$\begin{array}{l}\text { Growth rate class } \\
\left(\mathrm{mm} \mathrm{d}^{-1}\right)\end{array}$} & \multicolumn{8}{|c|}{ Growth interval (d post hatch) } \\
\hline & $1-10$ & $11-20$ & $21-30$ & $31-40$ & $41-50$ & $51-60$ & $61-70$ & $71-80$ \\
\hline \multicolumn{9}{|l|}{ Winter $1991-1992$} \\
\hline $0.00-0.04$ & 0 & - & - & - & - & - & - & - \\
\hline $0.04-0.08$ & 0 & - & - & - & - & - & - & - \\
\hline $0.08-0.12$ & 0.15 & 0.12 & 0 & 0 & - & - & - & - \\
\hline $0.12-0.16$ & 1.90 & 0.65 & 0.45 & 0.33 & 0.20 & - & 1.18 & 0.54 \\
\hline $0.16-0.20$ & 1.30 & 1.47 & 0.93 & 1.44 & 1.23 & 0.77 & 0.48 & 1.15 \\
\hline $0.20-0.24$ & 0.10 & 1.42 & 1.56 & 1.21 & 1.23 & 0.32 & 0.45 & 0.63 \\
\hline $0.24-0.28$ & 0 & 1.26 & 1.07 & 1.01 & 0.67 & 0.86 & 1.37 & 1.03 \\
\hline $0.28-0.32$ & - & - & 1.32 & 0.82 & 0.67 & 0.55 & 1.06 & $\infty$ \\
\hline $0.32-0.36$ & - & - & 2.64 & 0.89 & 1.64 & 2.45 & 2.36 & 2.05 \\
\hline $0.35-0.40$ & - & - & $\infty$ & 0.78 & 0.90 & 1.69 & $\infty$ & $\infty$ \\
\hline $0.40-0.44$ & - & - & - & $\infty$ & 3.69 & $\infty$ & $\infty$ & - \\
\hline $0.44-0.48$ & - & - & - & - & - & $\infty$ & $\infty$ & - \\
\hline $0.48+$ & - & - & - & - & - & - & - & $\infty$ \\
\hline \multicolumn{9}{|l|}{ Winter $1992-1993$} \\
\hline $0.00-0.04$ & - & - & - & - & & - & - & - \\
\hline $0.04-0.08$ & - & _- & - & _- & - & - & - & _- \\
\hline $0.08-0.12$ & 0.34 & - & - & - & - & - & - & - \\
\hline $0.12-0.16$ & 0.80 & 1.44 & 2.30 & 0.61 & 0.78 & - & 0 & $\infty$ \\
\hline $0.16-0.20$ & 1.15 & 0.67 & 0.57 & 0.62 & 0.33 & 0.22 & 0.38 & 0.54 \\
\hline $0.20-0.24$ & 5.09 & 1.20 & 0.77 & 0.48 & 0.28 & 0.26 & 0.30 & 0.51 \\
\hline $0.24-0.28$ & - & 167 & 0.74 & 1.04 & 0.49 & 0.68 & 1.20 & 1.35 \\
\hline $0.28-0.32$ & - & - & 2.52 & 0.96 & 1.01 & 1.73 & 6.23 & 1.71 \\
\hline $0.32-0.36$ & - & - & 4.59 & 0.87 & 3.50 & $\infty$ & 1.56 & 0.86 \\
\hline $0.36-0.40$ & - & - & - & 2.03 & 3.89 & $\infty$ & $\infty$ & $\infty$ \\
\hline $0.40-0.44$ & - & - & 1.15 & 3.48 & $\infty$ & 2.22 & 6.25 & - \\
\hline $0.44-0.48$ & - & - & - & $\infty$ & $\infty$ & $\infty$ & $\infty$ & $\infty$ \\
\hline $0.48+$ & & & & & & & & \\
\hline
\end{tabular}

between survivors and the population in the first winter (Fig. 6). In the second winter, the distribution of the hatch mark diameter of survivors was not significantly different from that of fish 1 to $40 \mathrm{~d}$ at capture, but the lack of statistical significance could be due to the small sample size for the population $(n=19)$. The distribution of hatch mark diameter of survivors was shifted significantly towards larger values relative to fish 41 to 60 and 61 to $90 \mathrm{~d}$ old at capture (Fig. 6).

In the first winter, the average hatch mark diameter did not differ significantly (GT2-test, $p>0.05$ ) between population $(28.10 \mu \mathrm{m}$, pooled data for the 1 to $90 \mathrm{~d}$ interval of age a: capture) and survivors $(28.33 \mu \mathrm{m})$ (Fig. $7)$. In the second winter, the average hatch mark of survivors $(29.02 \mu \mathrm{m})$ was significantly larger than that of the population $(27.36 \mu \mathrm{m})$. Interannually, the hatch mark diameter of the population was marginally larger in the first winter than in the second winter $(0.01<\mathrm{p}<$ 0.05 ). The average hatch mark diameter of survivors was not significantly different between winters (Fig. 7).

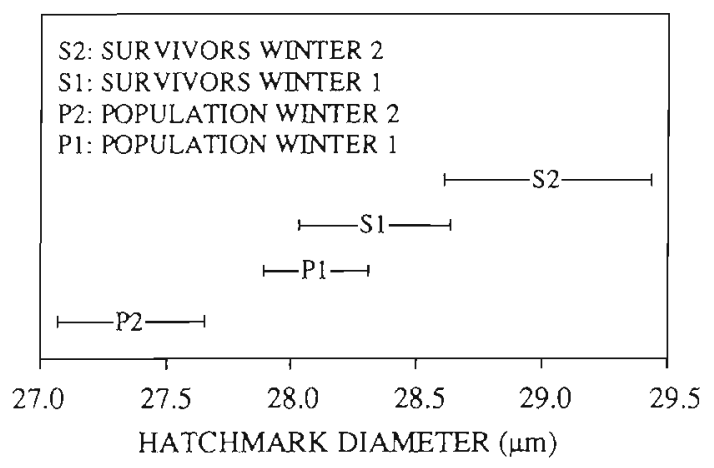

Fig. 7. Gadus morhua. Multiple comparison of mean hatch mark diameter among survivors (fish $>90 \mathrm{~d}$ at capture) and populations (fish $\leq 90 \mathrm{~d}$ at capture) of Atlantic cod sampled on the Scotian Shelf in the winters of 1991-1992 and 1992-1993. The confidence interval around each mean was calculated according to Gabriel (1978). Means whose confidence intervals do not overlap are significantly different from each other $(\alpha=0.05)$ 


\section{DISCUSSION}

\section{Sampling gears and selection for fast growth}

A key assumption of our analysis is that the 2 different sampling gears used did not select slow or fast growing fish. For example, if large, fast growing larvae and pelagic juveniles $<90 \mathrm{~d}$ of age avoided the RMT, the average growth rates or length at age of the population, which were sampled primarily by the RMT, may have been artifactually reduced relative to that of survivors which were captured primarily by the epibenthic net. When run with sampling gear as an additional grouping factor, the repeated-measures MANOVA of the growth rates and length at age of Atlantic cod indicated that the interaction between groups (population and survivors) and gears (RMT and epibenthic sampler) was significant (1991-1992, $p=0.029 ; 1992-1993$, $p=0.003$ ). We believe that this result primarily reflects the more epibenthic distribution adopted by juvenile Atlantic cod $>25 \mathrm{~mm}$ in length (Fahay 1983, Bolz \& Lough 1988, Perry \& Neilson 1988) and the resulting greater vulnerability of survivors to capture by the epibenthic sampler than by the RMT. The lack of significant differences in the size frequency distributions and average length of survivors captured by the RMT and the epibenthic sampler in a given winter (Fig. 3) indicates that both samplers efficiently captured older, larger fish, and supports the interpretation that the greater frequency of survivors in the epibenthic sampler was due primarily to the transition from pelagic to epibenthic life at lengths $>25 \mathrm{~mm}$. Yet, because of this change in habitat associated with survival, the relative contributions of selective mortality and gear selectivity to the observed selection for fast growers are confounded and cannot be separated statistically within a given year of sampling. Thus, the possibility that gear selection contributed to some extent to the observed selection of fast growing Atlantic cod cannot be rejected on statistical grounds.

Notwithstanding the above, the strongest argument against the hypothesis of a methodological artifact is that selection for fast growth was much stronger in the second year than in the first year. For example, at $70 \mathrm{~d}$ of age survivors in the first winter were on average $1 \mathrm{~mm}$ longer than the population (19.5 vs $18.5 \mathrm{~mm}$ ) whereas the difference reached $4 \mathrm{~mm}$ in the second winter (21 vs $17 \mathrm{~mm}$ ) (Fig. 4c). If artifactual, selection for fast growth and large length at age would have been equally important in the 2 years. We conclude that an eventual selection of fast growers by gear effects could not have been larger than the weak selection observad in the first yea dud illdi ine strong seiection observed in the second year, in excess of that in the first year, was due to selective mortality.

\section{Selection of fast growth during larval life in the plankton}

Recently, the hypothesis that fast growth enhances the probability of survival of young fish has became a central tenet in the study of recruitment determination in marine fish. Bertram (1993) reviewed 42 studies linking increased survivorship to fast growth. In most of these, the invoked link was largely inferential and only 3 of the 42 studies provided direct evidence of an interaction between growth and survival (Leggett \& Deblois 1994). Rosenberg \& Haugen (1982) examined the effects of starvation on turbot Scophthalmus maximus larvae in mesocosms and laboratory tanks from which predators were excluded. After 2 wk of planktonic life, the mortality of large individuals was less than that of smaller individuals. Rice et al. (1987) found that larval bloater Coregonus hoyi hatched early in the season in Lake Michigan (USA) exhibited slower growth and underwent higher mortality than faster growing larvae hatched later in the season. Hovenkamp (1992) reported that cohorts of larval plaice Pleuronectes platessa recruiting to a coastal nursery of the North Sea tended to comprise those individuals that were fast growing during planktonic life offshore. In addition to these 3 studies, Crecco \& Savoy (1985) found that larval cohorts of shad Alosa sapidissima hatched in spring exhibited lower growth rates and survival than fast growing larvae hatched in summer. Post \& Prankevicius (1987) reported intense selection for fast growers in a slow-growing cohort of yellow perch Perca flavescens and minimal size-selective mortality in a fast growing cohort. Titus \& Mosegaard (1991) showed that brown trout Salmo trutta fry recruiting to feeding territories were those fish with higher growth potential. In contrast, Amara et al. (1995) observed that a majority of Dover sole Solea solea settling in the coastal nurseries of Biscay Bay (France) were hatched in winter and had experienced relatively slow growth during early life in the plankton.

Consistent with the conclusions of most of these studies, our results support the hypothesis of a strong link, in some years, between fast growth and survival during early life of Atlantic cod on the Scotian Shelf. Selection for fast growth was detected over the age interval 40 to $80 \mathrm{~d}$ post hatch (12 to $20 \mathrm{~mm} \mathrm{SL}$ Fig 4c), which corresponded to the 40 d period preceding final metamorphosis from the larval to the juvenile form at sizes $>20 \mathrm{~mm}$ (Fahay 1983). The transition from a pelagic to a more epibenthic distribution occurs later at 25 to $50 \mathrm{~mm}$ in length (Fahay 1983, Perry \& Neilson 1988).

The growth rate and length at age of the survivors and the population were not significantly different in the first winter Moreover, between 51 and $70 \mathrm{~d}$ of age, the population in the first winter was longer at age 
than the population in the second winter. These results suggest that, in the first winter, conditions for growth (i.e. growth potential of offspring, feeding success and temperature) in late larval life were suitable while the factors operating the selection of fast growers (e.g. predation pressure) were mild. In contrast, the growth rate of the population in the second winter decreased sharply in fish $>40 \mathrm{~d}$ of age, whereas that of survivors reached the highest values observed in the present study (Fig. 4a). We suggest that, in the second winter, poor conditions in late larval life depressed the growth of most Atlantic cod, while harsh selection (presumably by predation) allowed only those fish achieving exceptional growth and length at age to survive. This strong selection of fast growers in the slow growing population of the second winter (and the weak selection for fast growth in the relatively fast growing population of the first winter), echo the results of Post \& Prankevicius (1987) who also found that selection for fast growth was stronger in a slow growing cohort of yellow perch than in a fast growing one.

The survival advantage provided by fast growth may be considerable. In the second winter the probability of survival through to the transition to epibenthic life was $>3$ times higher in fast growing than in slow growing pelagic juveniles (Table 3 ). A similar analysis indicated that slow growing larval plaice presented a 3 times lower chance of survival to almost complete metamorphosis than fast growing larvae (Hovenkamp 1992). Although the calculated survival ratios are indices of relative survival, a 3 -fold and larger difference in survivorship between fast and slow growing fish is consistent with the prediction of theoretical and simulation studies that changes in early growth rates have the potential to create large variations in the absolute number of fish surviving to metamorphosis (Chambers \& Leggett 1987, Houde 1987. Pepin \& Myers 1991, Cushing \& Horwood 1994). However, not all survivors were fast growing fish. Even in the winter 1992-1993, when selection for fast growth was strong, Atlantic cod survivors often presented back-calculated growth rates and lengths at age that were within the range of values of the population (Fig. 5). Similarly, in spite of size-selective mortality, some slow growing plaice survived to metamorphosis (Hovenkamp 1992). Thus, the slow growth phenotype is unlikely to be eradicated from populations in years when size-selective mortality is strong.

\section{Growth-dependent versus size-dependent selection for fast growth}

The match-mismatch (Cushing \& Harris 1973, Cushing 1990) and growth-predation. (Anderson
1988) hypotheses explain the preferential survival of fast growers by the reduction of the period of time during which young fish are vulnerable to pelagic predators (growth-dependent selection). The 'biggeris-better' hypothesis (Miller et al. 1988, Bailey \& Houde 1989) proposes that the larger size at age of the fast growers provides a survival advantage by reducing vulnerability to predators (size-dependent selection). Hovenkamp (1992) argued that the increased survivorship of fast growing plaice larvae could be explained solely by growth-dependent selection.

In the present study, some simple calculations suggest that both growth- and size-dependent predation could have operated the selection of fast growing Atlantic cod observed in 1992-1993. In this winter, survivors attained the size of $20 \mathrm{~mm}$ approximately 12 or $13 \mathrm{~d}$ younger than the population on average (Fig. 4c). Metamorphosis from larval to juvenile form and the transition from pelagic to epibenthic life is determined by size rather than age (Chambers et al. 1989, Amara \& Lagardère 1995). This implies that the duration of the pelagic stage of survivors was considerably shorter (by almost $2 \mathrm{wk}$ on average) than that of the general population. Assuming a daily mortality rate of 5 to $10 \% \mathrm{~d}^{-1}$ during the late larval stage (Dahlberg 1979, Bailey \& Houde 1989), the abundance of the population in the second winter would have been reduced by 50 to $75 \%$ during these additional $13 \mathrm{~d}$ of pelagic life. Alternatively, survivors may have avoided a 2 - to 4 -fold reduction of their numbers prior to the transition to epibenthic life by growing faster and reducing their larval life by $13 \mathrm{~d}$.

The average difference in length at age between survivors and the population over the 41 to $80 \mathrm{~d}$ age interval (when selection for fast growth was most intense) was approximately $2.8 \mathrm{~mm}$. In the laboratory, the evidence that the survivorship of young fish is increased by larger size at a given age is equivocal (Leggett \& Deblois 1994). For capelin Mallotus villosus and winter flounder Pleuronectes americanus larvae $<8 \mathrm{~mm}$, recent experimental studies that have controlled for the effects of both age and size on survival have found little indication that larger larvae are less vulnerable to predators than smaller individuals of the same age (Litvak \& Leggett 1992, Pepin et al. 1992, Bertram \& Leggett 1994). Indeed, these authors observed that larger, more active larvae were more likely to encounter ambush predators or to be perceived by visual predators. This conclusion applies to small larvae for which reduced mobility and conspicuousness are perhaps the best protection against predation. However, other laboratory studies have clearly demonstrated that the vulnerability of young fish to predators decreases rapidly in the 10 to $23 \mathrm{~mm}$ length 
range (e.g. Bailey 1984, Bailey \& Houde 1989, Fuiman 1989, Margulies 1990), which corresponds to the episode of intense selection for fast growth observed in the second year of our study. With the caveat that laboratory results cannot always be extrapolated to field situations (Bailey \& Houde 1989, Heath 1992), this suggests that the observed $2.8 \mathrm{~mm}$ difference in average length at age over the 41 to $80 \mathrm{~d}$ age interval could have contributed to the increased survivorship of fast growing Atlantic cod larvae on the Scotian Shelf in $1992-1993$.

\section{Early decimation versus fine tuning at metamorphosis: ontogenetic timing of selective mortality}

In Atlantic cod $<40 \mathrm{~d}$ of age, faster growth did not necessarily translate into persistent patterns of longer length at age among groups of larvae. For example, before $40 \mathrm{~d}$ of age, both survivors and the population grew faster in the second winter than in the first winter, but larvae in the second winter were not significantly larger at age (Table 2). By $40 \mathrm{~d}$, the growth rates and length at age of all 4 groups had converged towards similar values (Fig. 4). In largescale rearings, the range of specific growth rates of Atlantic cod declined between 20 and $30 \mathrm{~d}$ post hatch as individuals with low specific growth disappeared, presumably due to cannibalism (Øiestad et al. 1985). Similarly, in pond rearings, cannibalism was higher among starved $0.2 \mathrm{~g}$ Atlantic cod than fed $0.2 \mathrm{~g}$ cod and the surviving fish from the starved treatments were on average as heavy as the survivors from the fed treatments (Folkvord 1991). We suspect that before $40 \mathrm{~d}$ of age, when the larvae are presumably highly vulnerable to starvation and predation, slow growing Atlantic cod are rapidly eliminated from the population as predicted by the stochastic growth model of Beyer \& Laurence (1980). Because of this culling of slow growers, the actual intensity of size-or growth-dependent selection during the early larval stage may be impossible to evaluate. For example, the rapid decline in early specific growth during the first winter (Fig 4b) may have resulted in a critical period of high early larval mortality (sensu Hjort 1914). Such untraceable episodes of selection during the early larval stage could have a greater effect on recruitment than the more evident selective mortality found later in late larval life. Although central to our understanding of recruitment variability, the question of whether year class strength is determined by massive mortality during the early larval phase or by finer adjustments uuiriny uleidmorphosis remains largely unresolved (e.g. Bailey \& Houde 1989, Leggett \& Deblois 1994).

\section{Hatch mark diameter and survivorship}

In salmonids, a large otolith during the first weeks after hatching is not necessarily a correlate of large body size, but may be an indicator of high metabolic rate, fast growth and enhanced survivorship (Mosegaard et al. 1988, Mosegaard 1990, Titus \& Mosegaard 1991). In the laboratory, surviving Atlantic cod presented increasingly larger lapillar hatch mark diameters during the first $12 \mathrm{~d}$ post hatch, but this trend was not statistically significant (Geffen 1995). Similarly, in the first winter of the present study, when selection for fast growth was weak, the average hatch mark diameter of survivors was larger than that of the population, but not significantly so (Fig. 7). In the second winter, when selection was more intense, survivors presented significantly larger hatch mark diameters than the population (Fig. 7). This suggests that, as for salmonids, the potential for fast growth that was strongly selected for in the second winter of the present study was reflected in a large hatch mark diameter in Atlantic cod. If this interpretation is correct, we cannot reject the hypothesis that the growth potential selected for during the late larval life of Atlantic cod was present at hatching.

The growth potential reflected in hatch mark diameter could be inherited, may reflect maternal condition prior to spawning or could be environmentally forced. Campana (1989) reported that the hatch mark diameter of Atlantic cod larvae on Brown's Bank (Scotian Shelf, northwest Atlantic) was weakly but significantly and negatively correlated to temperature at hatching. In the present study, a larger average hatch mark diameter suggested a superior growth potential in the offspring produced in the first winter (Fig. 7). Temperatures prevailing in the well-mixed water column were on average $1.2^{\circ} \mathrm{C}$ lower in the first winter than in the second winter (monthly average of all profiles over the sampling grid, November: $8.8 \pm 2.5$ versus $10.1 \pm 2.7^{\circ} \mathrm{C}$; December: $6.3 \pm 1.7$ versus $7.4 \pm 2.0^{\circ} \mathrm{C}$ ). Once corrected for temperature using the regression for Brown's Bank (Campana 1989), interannual differences in the hatch mark diameter of the populations (Fig. 7) were no longer significant (GT2-test, $\mathrm{p}>0.05$ ). Thus, the higher growth potential presumably associated with larger hatch mark diameters in the first winter could have resulted from lower incubation temperatures during egg development.

\section{The counterweight to selection for fast growth}

Given that a considerable advantage in survivorship may accrue to larvae that attain large sizes quickly during pelagic life, why do Atlantic cod and other 
teleosts not produce very large offspring, as cartilaginous fishes do? The answer to this question may rest with the need to balance the selective pressures for large size and fast growth and the environmental uncertainty in marine ecosystems (Ware 1975). Atlantic cod are constrained to produce either a few large offspring (with shorter larval life) or many small offspring (with longer larval life) (Elgar 1990) since, for a given adult size, maximization of the size of progeny can only occur at the expense of fecundity (Smith \& Fretwell 1974). In years when conditions exist to sustain high rates of growth of larval cod, the extent of selection for fast growth will be minimal. Such conditions appear to have prevailed during late larval life in winter 1991-1992 on the Scotian Shelf. In these years, individual spawners that produce large numbers of (consequently) small offspring will gain some selective advantage. However, in years when selection for fast growth is strong (e.g. winter 1992-1993 on the Scotian Shelf), individuals that produce relatively few, large and presumably fast growing larvae will obtain a selective advantage. Assuming an inverse link between offspring number and growth potential, our results illustrate how the equilibrium between the conflicting requirements for fast growth and for large numbers of offspring may shift from year to year, resulting, over evolutionary time scales, in the production of larvae of a size and number that represent a compromise between opposing selective forces.

Acknowledgements. The Ocean Production Enhancement Network (OPEN), one of the Networks of Centres of Excellence supported by the Government of Canada through the Natural Sciences and Engineering Research Council of Canada (NSERC), provided funding for this research. Additional grants from NSERC and Employment and Immigration Canada to L.F. aided in the completion of laboratory analyses. We particularly thank T. J. Miller, T Herra and W. C. Leggett of the Biology Department, McGill University for allowing us to use their unpublished data. Discussions with T. J. Miller were helpful in the development of the manuscript. Numerous colleagues from McGill and Dalhousie Universities assisted with field work. Special thanks to L. Michaud, L. Natanson, G. Desbiens and M. Fortier for their contribution to the study. G. Bergeron, G. Chaumillon, S. Dauchez. L. Mousseau, G. Pascal, A. Potvin, M.-A. Rémillard, M. Simard and $C$. Velazquez assisted in the field and in the laboratory. The comments of 3 anonymous referees helped improve an earlier version of the manuscript

\section{LITERATURE CITED}

Amara R, Lagardère F (1995) Taille et âge au début de la métamorphose chez la sole (Solea solea (L.)) du golfe de Gascogne. ICES J Mar Sci 52:247-256

Amara $R$, Desaunay $Y$, Lagardère $F$ (1995) Seasonal variation in growth of larval sole Solea solea (L.) and consequences on the success of larval immigration. Neth J Sea Res 32: $287-298$

Anderson JT (1988) A review of size-dependent survival dur- ing pre-recruit stages of fishes in relation to recruitment J Northwest Atl Fish Sci 8:55-66

Bailey KM (1984) Comparison of laboratory rates of predation on five species of marine fish larvae by three planktonic invertebrates: effects of larval size on vulnerabrlity. Mar Biol 79:303-309

Bailey KM, Houde ED (1989) Predation on eggs and larvae and the recruitment problem. Adv Mar Biol 25:1-83

Bergstad OA (1984) A relationship between the number of growth increments on the otoliths and the age of larval and juvenile cod Gadus morhua L. In: Dahl E. Damelssen D, Moksness E, Solemdal P (eds) The propagation of cod Flødevigen Rapportser 1:251-272

Bertram DF (1993) Growth, development and mortality in metazoan early life histories with particular reference to marine flatfish. PhD thesis, McGill University, Montreal

Bertram DF, Leggett WC (1994) Predation risk dunng the early life history periods of fishes: separating the effects of size and age. Mar Ecol Prog Ser 109:105-114

Beyer JE, Laurence GC (1980) A stochastic model of larval fish growth. Ecol Model 8:109-132

Bolz GR, Lough RG (1988) Growth through the first six months of Atlantic cor. Gadus morhua, and haddock, Melanogrammus aeglefinus, based on daily otolith increments. Fish Bull US 86:223-235

Campana SE (1989) Otolith microstructure of three larval gadids in the Gulf of Maine, with inferences on early life history. Can I Zool 67:1401-1410

Campana SE (1990) How reliable are growth back-calculations based on otoliths? Can J Fish Aquat Sci 47:2219-2227

Campana SE, Hurley PCF (1989) An age and temperaturemediated growth model for cod (Gadus morhua) and haddock (Melanogrammus aeglefinus) larvae in the Gulf of Maine. Can J Fish Aquat Sci 46:603-613

Campana SE, Jones CM (1992) Analysis of otolith microstructure data. In: Stevenson DK, Campana SE (eds) Otolith microstructure examination and analysis. Can Spec Publ Fish Aquat Sci 117:73-100

Campana SE, Neilson JD (1985) Microstructure of fish otoliths. Can J Fish Aquat Sci 42:1014-1032

Chambers RC, Leggett WC (1987). Size and age at metamorphosis in marine fishes: an analysis of laboratory-reared winter flounder (Pseudopleuronectes americanus) with a review of variation in other species. Can J Fish Aquat Sci 44:1936-1947

Chambers RC, Leggett WC, Brown JA (1989). Egg size, female effects, and the correlations bitween early life history tratts of capelin Mallotus villosus: an appraisal at the individual level. Fish Bull US 87:515-523

Chambers RC, Miller TJ (1995) Evaluating fish growth by means of otolth increment analysis: sperial properties of individual level longitudinal data. In: Secor DS, Dean J, Campana SE (eds) Recent developments in fish otolith research. University of South Carolina Press, Columbia p $155-175$

Crecco VA, Savoy TF (1985) Effects of biotic and abiotic factors on growth and relative survival. of young American shad, Alosa sapidissima, in the Connecticut River Can J Fish Aquat Sci 42:1640-1648

Cushing DH (1990) Plankton production and year-class strength in fish populations: an update of the match/mismatch hypothesis. Adv Mar Biol 26:142-155

Cushing DH, Harris JGK (1973) Stock and recruitment and the problem of density dependence. Rapp PV Réun Cons Int Explor Mer 164:142-155

Cushing DH, Horwood JW (1994) The growth and death of fish larvae. J Plankton Res 16:291-300 
Dahlberg MD (1979) A review of survival rates of fish eggs and larvae in relation to impact assessments. Mar Fish Rev 41:1-12

Dale T (1984) Embryogenesis and growth of otoliths in the cod (Gadus morhua L.). In: Dahl E, Daniclssen D, Moksness E, Solemdal P (eds) The propagation of cod. Flodevigen Rapportser 1:231-250

Elgar MA (1990) Evolutionary compromise between a few large and many small eggs: comparative evidence in teleost fish. Oikos 59:283--287

Fahay MP (1983) Guide to the early stages of marine fishes occurring in the western North Atlantic Ocean, Cape Hatteras to the southern Scotian Shelf. J Northwest Atl Fish Sci $4: 1-423$

Folkvord A (1991) Growth, survival and cannibalism of cod juveniles (Gadus morhua): effects of feed type, starvation and fish size. Aquaculture 97:41-59

Fuiman LA (1989) Vulnerability of Atlantic herring larvae to predation by yearling herring. Mar Ecol Prog Ser 51. $291-299$

Gabriel KR (1978) A simple method of multiple comparisons of means. J Am Stat Assoc 73:724-729

Gagné JA, O'Boyle RN (1984) The timing of cod spawning on the Scotian Shelf. In: Dahl E, Danielssen D, Moksness E, Solemdal P (eds) The propagation of cod. Flødevigen Rapportser 1:501-518

Geffen AJ (1995) Growth and otolith microstructure of cod (Gadus morhua L.) larvae. J Plankton Res 17:783-800

Girden ER (1992) ANOVA: repeated measures. Sage University paper series on quantitative applications in the social sciences, 07-084. Newbery Park, CA

Healey MC (1982) Timing and relative intensity of size-selectuve mortality of juvenile chum salmon (Oncorhynchus keta) during early sea life. Can J Fish Aquat Sci 39:952-957

Heath MR (1992) Field investigations of the early life stages of marine fish larvae. Adv Mar Biol 28: 1-174

Hjort $\mathbf{J}$ (1914) Fluctuations in the great fisheries of northern Europe viewed in light of biological research. Rapp PV Réun Cons Perm Int Explor Mer 20:1-228

Houde ED (1987) Fish early life dynamics and recruitment variability. Am Fish Soc Symp 2:17-29

Hovenkamp F (1992) Growth-dependent mortality of larval plaice Pleuronectes platessa in the North Sea. Mar Ecol Prog Ser 82:95-101

Leggett WC, Deblois E (1994). Recruitment in marine fishes: is it regulated by starvation and predation in the egg and larval stages? Neth J Sea Res 32:119-134

Litvak MK, Leggett WC (1992) Age and size-selective predation on larval fishes: the bigger-is-better hypothesis revisited. Mar Ecol Prog Ser 81:13-24

Margulies D (1990) Vulnerability of larval white perch, Morone americana, to tish predation. Environ Biol Fish 27:187-200

Miller TJ, Crowder LB, Rice JA, Marschall EA (1988) Larval size and recruitment mechanisms in fishes: toward a conceptual framework. Can J Fish Aquat Sci 45:1657-1670

Mosegaard $H(1990)$ What is reflected by otolith size at emergence? A reevaluation of the results in West and Larkin (1987). Can J Fish Aquat Sci 47:225-228

Mosegaard $H$, Svedäng $H$, Taberman K (1988) Uncoupling of somatic and otolith growth rates in Arctic char (Salvelinus alpinus) as an effect of differences in temperature response. Can J Fish Aquat Sci 45:1514-1524

O'Boyle RN, Sinclair M. Conover R.I Mann KH, Kohler AC (1984) Temporal and spatial distribution of ichthyoplankton communities of the Scotian Shelf in relation to biological hydrological, and physiographic features. Rapp PV
Réun Cons Int Explor Mer 183:27-40

Øiestad V, Folkvord A, Kvenseth PG (1985) Growth-patterns of Atlantic cod larvae (Gadus morhua L.) from first feeding to metamorphosis studied in a mesocosm. ICES Counc Meet, Mini-Symp 9:1-10

Pannella G (1971) Fish otoliths: daily growth layers and periodical patterns. Science 173:1124-1127

Pepin P, Myers RA (1991) Significance of egg and larval size to recruitment variability of temperate marine fish. Can J Fish Aquat Sci 48:1820-1828

Pepin P, Shears TH, de Lafontaine $Y$ (1992) Significance of body size to the interaction between a larval fish (Mallotus villosus) and a vertebrate predator (Gasterosteus aculeatus). Mar Ecol Prog Ser 81:1-12

Perry IR, Neilson JD (1988) Vertical distributions and trophic interactions of age-0 A.tlantic cod and haddock in mixed and stratified waters of Georges Bank. Mar Ecol Prog Ser 49:199-214

Post JR, Prankevicius AB (1987) Size-selective mortality in young-of-the-year yellow perch (Perca flavescens): evidence from otolith microstructure. Can J Fish Aquat Sci $44: 1840-1847$

Rice JA, Crowder LB, Holey ME (1987) Exploration of mechanisms regulating larval survival in Lake Michigan bloater: a recruitment analysis based on characteristics of individual larvae. Trans Am Fish Soc 116:703-718

Rosenberg AA, Haugen AS (1982) Individual growth and size-selective mortality of larval turbot (Scophthalmus maxımus) reared in enclosures. Mar Biol 72:73-77

Sherman K, Smith WG, Morse WW, Bergman M, Green J, Ejsymont L (1984) Spawning strategies of fishes in relation to circulation, phytoplankton production and pulses of zooplankton off the northeastern United States. Mar Ecol Prog Ser 18:1-19

Smith CC, Fretwell SD (1974) The optimal balance between size and number of offspring. Am Nat 108:499-506

Smith WG, Morse WW (1985) Retention of larval haddock Melanogrammus aeglefinus in the Georges Bank region, a gyre-influenced spawning area. Mar Ecol Prog Ser 24:1-13

Sokal RS, Rohlf FJ (1981) Biometry. Freeman, New York

Stevenson DK, Campana SE (1992) Otolith microstructure examination and analysis. Can Spec Publ Fish Aquat Sci 117:1-126

Suthers IM, Frank KT (1989) Inter-annual distributions of larval and pelagic juvenule cod (Gadus morhua) in southwestern Nova Scotia determined with two different gear types. Can J Fish Aquat Sci 46:591-602

Suthers IM, Frank KT, Campana SE (1989) Spatial comparison of recent growth in postlarval Atlantic cod off southwestern Nova Scotia: inferior growth in a presumed nursery ared. Can J Fish Aquat Sci 46:113-124

Suthers IM, Sundby S (1993) Dispersal and growth of pelagic juvenile Arcto-Norwegian cod (Gadus morhua), inferred from otolith microstructure and water temperature. ICES J Mar Sci, 50:261-270

Titus RG, Mosegaard H (1991) Selection for growth potential among migratory brown trout (Salmo trutta) fry competing for territories: evidence from otoliths. Can J Fish Aquat Sci $48: 19-27$

Tsukamoto K, Kuwada H, Hirokawa J, Oya M, Sekiya S, Fujimoto H, Imaizumi K (1989) Size-dependent mortality of red sea bream, Pagrus major, juveniles released with fluorescent otolith-tags in News Bay, Japan. J Fish Biol 35 \{ripipl A\} $\} .59-69$

Ware DM (1975) Relation between egg size, growth, and natural mortality of larval fish. J Fish Res Bd Can 32: $2503-2512$

Manuscript first received: July 4, 1995

Revised version accepted: March 4, 1996 